\title{
On Some Mural Paintings Recently Discovered in the Churches of Little Horwood and Padbury, Buckinghamshire
}

\section{Charles E. Keyser M.A., F.S.A.}

To cite this article: Charles E. Keyser M.A., F.S.A. (1892) On Some Mural Paintings Recently Discovered in the Churches of Little Horwood and Padbury, Buckinghamshire, Archaeological Journal, 49:1, 333-344, DOI: 10.1080/00665983.1892.10852530

To link to this article: $h$ ttp://dx.doi.org/10.1080/00665983.1892.10852530

电 Published online: 15 Jul 2014.

Submit your article to this journal $[\pi$ 
ON SOME MURAL PAINTINGS RECENTLY DISCOVERED IN THE CHURCHES OF LITTLE HORWOOD AND PADBURY, BUCKINGHAMSHIRE.'

By CHARLES E. KEYSER, M.A., F.S.A.

Many interesting mural paintings have been brought to light in recent years in the churches in the northern part of the county of Buckingham. In the neighbourhood of Winslow several examples have been noted, in addition to those at Little Horwood and Padbury, which will be more fully described. At Adstock various subjects were discovered and again whitewashed over. At Whaddon a very interesting series, including the murder of St. Thomas of Canterbury, Les trois rois vifs et les trois rois morts, King Edmund and a Bishop, and symbolical figures of the Evangelists have been again whitewashed over. ${ }^{2}$ At Shenley Mansel are some early paintings, viz., in the south transept, Adam and Eve after their expulsion from the Garden of Eden, Noah looking out of the Ark, and traces of other scriptural subjects, and there is also some scroll foliage on the soffit of the western arch on the south side of the nave of date circc 1200, and crimson colouring on the western arch of the north nave arcade, about a century later. At Swanbourne in the north-east corner of the north aisle, is a somewhat obscure subject, but it has been described as representing the various conditions of the Soul after death. ${ }^{3}$ At Uving another doubtful subject has been found at the side of the chancel arch; it is supposed to portray a Representative Christian surrounded by various implements. At Winslow some interesting paintings were laid bare in 1884, and are still preserved. By the side of the north doorway are portions of the well-known subject of St. Christopher, the upper part with the Infant Saviour

Read at the monthly meeting of the Institute, June 1st, 1892.

- Arcliacological Journal, xxiii, 78; Norfolk Archæologia, vi, 167 ; Records of
Buckinghamshire, iii, 270.73; Sheahan, History and Topography of the County of Buckingham, p. 70 .

3 Records of Buckinghamsbire, iii. 136. 
on the shoulder of the Saint remaining in a fair state of preservation. Traces of other subjects, which have not yet been explored, are visible through the whitewash over and to the west of the doorway. Between the two eastern windows of the north aisle is the martyrdom of St. Thomas of Canterbury. Tablets have been let into the wall, materially interfering with both these paintings, which appear to date from about the middle of the fourteenth century.

The Church of St. Nicholas, Little Horwood, where the paintings have been recently discovered, of which it is now proposed to give a somewhat detailed description, is situated about two miles and a half from Winslow, and has been carefully restored. It consists of a west tower, nave, south aisle and chancel. The chancel which had previously been much churchwardenized, has been greatly improved, and a nice three-light east window of geometrical character, and a similar one of two lights in the north and south walls, has been introduced. There is a trefoiled arched piscina in the usual position, and a plain sedile within the sill of the east window on the south side. At the west end of the chancel is a single light square-headed window of the late fifteenth century date on the north, and a two light decorated window on the south side. These are set lower in the wall so as to form the low side windows so commonly found in this situation. There is a south chancel doorway of good decorated character. The chancel arch is also decorated with two recessed orders, the inner resting on slender semioctagonal jamb shafts. In the nave is some earlier work. The arcade separating the nave from the aisle consists of four arches, with continuous hood-mould, and two chamfered orders obtusely pointed and resting on circular columns, the two east with octagonal capitals and abaci, while the western and two responds have circular capitals. These clearly date from about the year 1200, and a plain blocked doorway in the north wall seems to be of the same early period. The roofs of the chancel and nave are new, but that of the aisle is a lean-to of the fifteenth century. In the east wall of the aisle is an image bracket, and a blocked up squint formerly pierced the wall to the chancel so as to afford a view of the High Altar. In the south wall are two square-headed perpendicular windows, and at the west 
end, a three-light window of decorated date with intersecting mullions. On the north of the nave are two large windows of three lights in the perpendicular style, but set within containing arches of an earlier date. The pulpit is of seventeenth century date. On the south side of the chancel arch is a very curious brass plate with the date 1641 . On it is engraved the beginning of each of the ten Commandments, and a rhyming inscription of eight verses, and below, the eighteenth and nineteenth verses of the fifth chapter of St. Matthew's Gospel. ${ }^{1} \quad$ The tower arch is fourcentred perpendicular with hood-mould and two hollow chamfered orders. The tower itself is composed of very large stones and is embattled perpendicular in three stages, with nice belfry lights, a three-light west window of very good design and a west doorway with four-centred arch. The whole of this work is of somewhat late date and of excellent character. The south doorway within a porch is of the decorated period with hood-mould and two hollow chamfered orders, probably of the end of the thirteenth century. The outer arch of the porch is four-centred and late perpendicular. There are thus, at least, three if not four different styles of architecture in the Church of dates ranging from the beginning of the thirteenth to the end of the fifteenth century.

Some notes taken on a previous visit to the Church in 1881 bear record that the walls were then particularly well crusted with whitewash, and it was while clearing this away that the paintings were brought to light in 1889 . Considerable remains of red colouring were found on various parts of the Church, and the subjects, of which some photographs are exhibited, on the north wall of the nave between the two windows and nearly facing the main south entrance. There have been at least three layers of subjects painted one over the other. Of the earliest series only the lower portion remains, and here are apparently two, probably out of several, scenes illustrating the history of St. Nicholas, the Patron Saint of the Church. The eastern one shows the figures of three soldiers in mail, one grasping a spear, apparently entering a house, the lower part alone being visible. This may be intended to portray the subject of one of the miracles attributed to the Saint,

' Lipscomb's History of Buckinghamshire, iii., 390. 
viz., the three knights coming to claim as their brides the three daughters of a certain nobleman, who had each received a bag of gold in answer to the prayer of the Saint, and had thus been saved from the necessity of earning a livelihood by an immoral course of life. This definition of the subject would appear too conjectural were it not for the fact that the remainder of the painting seems to be more easy of identification. In this is a large tub or barrel standing up on end, and from the upper side are emerging two nude figures, a third is probably still concealed under the later painting; on one side is the lower portion of a bishop, clearly distinguishable by his vestments, and on the other of another figure. This, no doubt, represents the miracle of the bringing to life of the three students, who had been treacherously murdered and packed in a barrel to be sold as salted pork. The barrel is painted grey with upright bands of yellow and horizontal bands of red. Both these miracles are represented on the Norman font at Winchester Cathedral, and in other later examples. A masonry pattern of double lines enclosing roses remains below the subjects. The whole is on a pale yellow ground and the date appears to be of the latter half of the thirteenth century.

Of the second series of paintings not much is visible. Near the west side, of the picture a small portion of a knight in armour remains apparently of date circa, 1360. Above is part of a subject also of this date, with the lower limbs of a human figure, but nothing else capable of identification. At each extremity is some scroll work on a red ground, which seems to be also of this date.

Of the latest and most interesting series, three subjects remain. The eastern is very indistinct, but a little patient observation will prove it to be the familiar legend of St. Christopher. The head of the Saint can be made out, also his tunic, legs and staff. He is walking from east to west, and in the water which reaches nearly up to his knees, is a most extraordinary medley of fish and other strange looking monsters. The figure of our Lord on the shoulder of the Saint cannot be made out, nor can the attendant hermit or other usual adjuncts of the picture be discerned. Above the head of the Saint is a scroll with inscription, apparently in English, and similar to those 


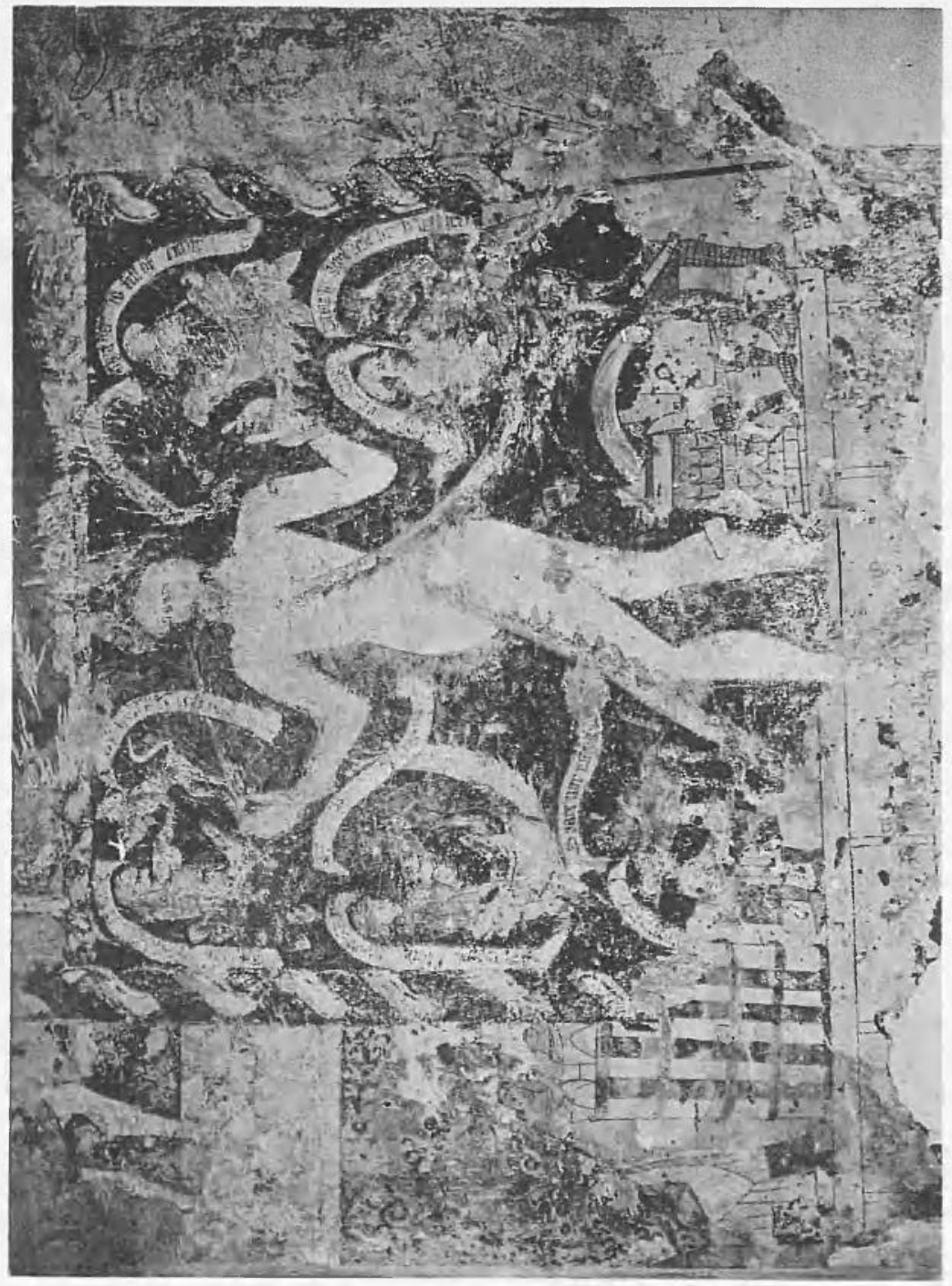


connected with the'more important picture to the west of it; a scalloped border in red and white is carried along above it.

Immediately adjoining this is the very curious and interesting painting, which forms the main object of the present paper. On a deep crimson ground, bordered on either side by a cable band in yellow and white, is a large nude figure, apparently moving from east to west, and with extended arms. The figure is between six and seven feet high, though the lower portion is gone, and from different portions of the body proceed jagged scrolls which terminate in a monster inverted head with horns and open jaws, over and within which the several subjects are portrayed. Here is of course a representation of the Morality of Pride and her Six Daughters. or the purging of the Seven Deadly Sins. It is somewhat difficult to identify the individual sins, as though portions of inscriptions on scrolls still remain in connection with each subject, they are too imperfect to admit of being deciphered. On the dexter (west) side of the figure of pride, a jagged scroll proceeds from the mouth, and above the monster jaws is a figure apparently greedily drinking out of a bowl, which an attendant demon or shade is holding with one hand, while with the other he is filling the bowl from a flagon. This is no doubt the vice of "Ebrietas," drunkenness more covimonly represented under the head of "Gula " gluttony. The next subject on this side is appended to the right wrist and apparently represents "Avaritia," avarice, a figure holding what appear to be money bags, which the attendant demon is attempting to drag away. The lowest on this side is clearly "Luxuria," lust, a male and female portrayed within the monster mouth, and the attendant demon above. Above part of the inscription with the words "spare nor" can be made out. On the sinister, east side the upper subject is at the end of the scroll which is attached to the left hand. Here is an indistinct figure with attendant demon sinking down into the monster jaws, while on the scroll above occur the words "is full of envye" proving this to be a representation of "Invidia," envy. Below and attached to a scroll coming from the heart is "Ira," wrath, a figure with a villainous expression clasping a short sword and the attendant demon in front. The inscrip- 
tion in connection with this one might perhaps with a little patience be deciphered. The lowest subject on this side has been scraped away, though a portion of the inscription remains. This will, however, if the interpretation of the others be correct, have been Sloth, in some instances denominated "Socordia," and in others "Accidia."

Above this painting is a portion of another indistinct subject, apparently of the same date, as it is bounded on either side by the cable border.

There is not much to guide one in assigning a date to these subjects of Pride and St. Christopher, but from their general treatment, and the English inscriptions on the scrolls, they can hardly be earlier than the year 1500 , or certainly very late in the fifteenth century, and they were probably executed soon after the building of the tower, and the insertion of the perpendicular windows in the walls of the chancel, nave, and aisle. Another large subject was found on the north wall of the nave to the east of the easternmost of the two windows, but, unfortunately, was not preserved.

Before proceeding with the subject of the painting of Pride, and the mode in which it is treated in the various examples which have come to light, a short divergence may now be made to Padbury (about five miles from Little Horwood, and on the high road from Winslow to Buckingham), where an earlier and equally interesting instance of this same Morality has also been recently found and is still preserved. ${ }^{1}$

Padbury Church, dedicated to the Blessed Virgin Mary, consists of a west tower, nave, aisles and chancel, and is an excellent specimen of a small country church. The present tracery of the east window of the chancel is good perpendicular work, but the external hood-mould, terminating on masks, of the containing arch is probably considerably earlier. On the south side is a three-light decorated window, and an early English double lancet on the north. There is a nice ogee headed decorated piscina, with cinquefoiled fringe, and the wooden shelf still remaining, in the south wall. To the east of it are two plain oblong openings. On either side at the west end of the chancel

1 Padbury Church was visited after the original paper on the Little Horwood

paintings was read on June 1st, 1882. 
is an early low side window, of late twelfth or early thirteenth century date; that on the soutb has a semicircular head to the inner splay. The wall plate and one old beam of the chancel roof has been preserved, with a head of our Saviour carved on it. The chancel arch is massive, and obtusely pointed of transitional Norman character, with plain responds and square abaci. On either sicle of the nave is an arcade of four arches on octagonal columns. Those on the south are early English, and slightly earlier than those on the north, which are of early decorated date. Both arcades terminate east and west on brackets resting on heads, with the exception of the southeast respond. Some red colouring remains on the eastern arch of the north arcade. Above, but not corresponding with the arches, are clerestory windows. There are four of three lights of perpendicular style on the south, and on the north three plain circular openings, the central enclosing a quatrefoil and each of the others a sixfoil, all probably coeval with the arcade below. Traces of similar circular openings are visible externally on the south side. The nave roof is old, the eastern beam has a series of roses carved on it and formerly painted red. The aisle roofs are also old. In the south aisle are three square-headed perpendicular windows of very poor and, perhaps, debased character, and an original double lancet at the west end. There is a trefoiled arched piscina, with a course of dogtooth on the edge of the arch and jambs, and to the west of it a trefoil headed recess, ? for an aumbrey. The font is small and very early, and is probably the ancient stoup. It is cup-shaped, and stands on an octagonal stem. The two windows on the north side of the north aisle are decorated, while the east is of three lights square headed perpendicular, similar to those in the south aisle. In the east wall at east end of north aisle is a small ogee-headed decorated piscina, and in the north wall, near the east end, is a decorated arched recess for an Easter sepulchre or Founders tomb, within which an ancient chest now stands. The tower arch is transitional from early English to decorated of three orders, the two outer dying into the wall, and the inner resting on brackets. On the exterior there is not much worthy of notice. The tower is debased. The south doorway, within a porch, is good early English, 
with a hood-mould terminating on heads, and enriched with the nail-head and dog-tooth ornaments, and two hollow chamfered orders. There is a nice decorated doorway on the north side.

The paintings to which reference has already been made were discovered in 1883 , and still remain on the north wall at the east end of the north aisle, above and no doubt coeval with the segmental arched recess. Traces of colouring are visible all along the north wall, and two courses at least of other designs were displaced before the present series were brought to light. As at Little Horwood there are two distinct subjects placed side by side. That on the east portrays two scenes from the history of St. Catherine. In the upper one is the Saint with golden hair and the upper part of her body bare and arms tied behind her back, between the wheels by which she was to be torn in pieces, while at the side is the Emperor seated holding the sword of state in his hand. The ground-work of this part of the picture is a pale yellow, with a powdering of leaves, \&c., upon it. Below is St. Catherine again standing and holding out her hand to two figures to the west of her, one is a male with short tunic holding some undistinguishable object in his hand, the other is perhaps a female in rich apparel and kneeling, while another indistinct figure is discernible in the background. The ground colour is a pale pink. The subject probably represents the conversion and execution of the Empress, which is usually included in the scenes illustrating the history of this most popular Saint. An early scroll border in red encloses these two paintings.

Immediately to the west of it is a large wheel or circle about six feet in diameter containing a representation of the Purging of the Seven Deadly Sins. ${ }^{1}$ It is not very clear, but there can be no doubt as to the subject. In the centre is a female figure richly clothed, and with an early crown of the style of the latter part of the thirteenth century, and with scrolls terminating in monster heads with the representative sin and its attendant demon above, coming from various portions of her body. In the south east corner is a somewhat realistic representation of

1 In "the List of Buildings having Mural Decorations," Sce, this is erron-

eously described from information received as "a wheel of fortune." 
"Luxuria." Above this is a figure holding a sack across the shoulders, which may be intended for "Avaritia," and another representative sin is portrayed by a soldier probably for "Ira." None of the others can be made out, though all the monster heads, which are varied in each case are clearly discernible. Outside the circle or wheel is a large gaunt figure of Death, with spikes or claws on his knees and elsewhere. He is thrusting a long pole or spear into the side of Pride, as in the example at Raunds, in Northamptonshire. The lower part of the figure of Pricle has not been divested of the whitewash. Probably, here, as at Raunds, flames have been depicted. Below, and slightly to the west of this subject is a consecration cross. It is a red Maltese cross, but not as is usually the case, within a circular border.

There can be no doubt that these paintings are coeval with, and in some way identified with the recess over which they are painted. There has clearly been a Chantry Chapel of some importance at the east end of this aisle, and it may have been founded and endowed by the Monks of Bradwell Priory, who "appropriated the great tithes and procured the endowment of a Vicarage by the Bishop 8th June 1274." "This date will fairly correspond with the style of the architecture and the distinctive features of the paintings, which are therefore of about the same date as the earliest series at Little Horwood.

It is a somewhat curious coincidence that this subject of Pride and her Six Daughters, or the Purging of the Seven Deadly Sins, which is by no means a common one, should be found in these two neighbouring churches, and further that, although there have been one or two later layers of paintings covering over the example at Padbury, so that it is hardly probable that it was visible or even known at the time the Little Horwood example was executed, yet there are certain common peculiarities of treatment of this subject, such as have been noticed only in three other instances in mural painting in England:

In an admirable paper read before this Society by $\mathrm{Mr}$. J. G. Waller, F.S.A., on the very interesting series of paintings at Raunds, in Northamptonshire, where the finest example of the subject of the Purging of the Seven Deadly

${ }^{1}$ Lipscomb's History of Buckingham, iii, 59. 
Sins has been discovered, the origin of this Morality and the references to it by the various early writers are fully set out. It will, therefore, be unnecessary to traverse the same ground again, or to do more than refer those who wish to obtain all the information which can be acquired to Vol. xxxiv., pp. 221-227 of the Archooological Journal. It is, however, worthy of repetition, that one of the earliest treatises on this Morality is to be found in the writings of Csesarius, a monk who flourished in Germany in the twelfth and thirteenth centuries. Here is a dialogue on Temptation, and one chapter is entitled "Pride and her Six Daughters," which sets out the Sins as they are found at Little Horwood. ${ }^{1}$

In mural paintings in our English churches, this subject is represented in four different ways :-

First simply with an illustration of each Sin within a series of medallions or compartments, and generally in juxta-position with the Seven Acts of Mercy. Examples of this mode of treatment have been found at Cropred ${ }^{2}$ and Milcomb, ${ }^{3}$ in Oxfordshire; at Milton Abbas ${ }^{4}$ and Netherbury, ${ }^{5}$ in Dorsetshire ; at Brooke ${ }^{6}{ }^{3}$ Norfolk, and probably treated in this way at Brunstead and Dallam in the same county. On the screen at Catfield, ${ }^{7}$ in Norfolk, three of the Sins are depicted on the panels.

Secondly, they are represented within medallions enclosed within a circle or wheel, as at Arundel in Sussex, or between the spokes as at Ingatestone in Essex.? These

1 On the very interesting late Norman Fonts at Stanton Fitzwarren Church, Wiltshire, and Southrop, Gloucestershire, are sculptured representations of the Virtues trampling on the Vices. At Stanton Fitzwarren (figured in Van Voorst's "Illustrations of Baptismal Fonts," and the "Builder," Vol. iii. p. $6)$, we have a sculpture of "Ecclesia" with inscription "Serpens occiditur," and another of "Cherubyn," and the following Virtues triumphing over the Vices, viz., "Largitus and Avaricia," "Humilitas and Superbia," "Pietas and Discordia," "Misericordia and Invidia," "Modestia and Ebrietus," "Temperancia and Luxuria," "Paciencia and Ira," "Pudicicia and Libido."

In the example at Southrop is "Moises" between "Fcclesia" and
"Sinagoga," and pointing towards the former, and within a series of trefoiled arches, as at Stanton Fitzwarren. "Misericordia and Invidia," "Temperancia und Luxuria," "Largitas and Avaricia," "Patiencia and Ira," "Modestia and Ebrietas."

2 Builder, 1876, p. 939.

3 Builder, 1864, p. 734 .

4 Hutchin's History of Dorset, 3rd. ed., Voi, iv,, p. 403 .

5 Ecclesiologist, xi., 251, xii.. 59.

6 Norfolk Archæologia, iii., 62.

7 Archrological Journal, xxxiv., 224.

8 British Archeological Association .Tournal, vi., 440 ; Archæologia, xxxviii., 432.

9 Archæological Journal, xxxiv., 224.

There is a coloured drawing in the Art Librn: South Kensington Museum. 
examples seem to correspond in some respects with that at Padbury.

Thirdly, we have the representation of a tree standing over the jaws of hell, and the Sins depicted at the end of branches proceeding from the parent stem of Pride, who is portrayed either as a figure at the top of the tree, or by one or more trumpeters. Of this form of treatment examples have been noted at Catfield, ${ }^{1}$ Crostwight, ${ }^{2}$ and Stokesby, ${ }^{3}$ Norfolk; and Bardwell ${ }^{4}$ and Hessett, ${ }^{5}$ Suffolk. At St. John the Baptist's Church, Bristol, ${ }^{6}$ is also a tree, and at the stem and descending into the open jaws of Hell are the representative figures of the Vices, with their names on scrolls above them, Superbia in the centre. At Lyddington, in the county of Rutland, a painting of this subject has been recently found over the north doorway, but it is in a bad state of preservation and very indistinct. Only " Tra" and "Luxuria" can be identified.

Of the fourth class, viz., with the figure of Pride, only three other examples, besides those at Little Horwood, Padbury, and probably Arundel, have, it is believed, been noticed. By far the finest is that already referred to at Raunds, where Pride is represented as richly attired and crowned, and this apparently belongs to the end of the fourteenth century. At Wisborough Green, Sussex, ${ }^{7}$ mention is made of a nude figure, whence are being expelled the other sins, and this seems to correspond in its treatment with the example at Little Horwood. At Alveley, in Shropshire, on the south wall of the south aisle or chapel is another illustration of this subject, and a connecting link between those at Raunds and Little Horwood. Here is a large nude female figure crowned, and with scrolls terminating in demons issuing from various portions of her body. A trumpeter stands above her, and a skeleton, figurative of Death, as at Padbury, by her side. The ground is diapered with roses, and the painting may be of the fourteenth century. Amongst the interesting series of paintings found at Trinity Chapel, Stratford on Avon, and illustrated by Fisher, ${ }^{8}$ is a repre-

1 Norfolk Archmologia, i.. 133.

2 Norfolk Archæologia, ii., 355.

"Norfolk Archæologia, v., 292.

4 Suffolk Archacologia, ii., 43.

5 Suffolk Archæologi it, v., 29.

There is a coloured drawing in the
Society of Antiquaries' Library.

7 Archæological Journal, xxxiv., 223.

8 Thomas Fisher, A series of antient allegorical . . . and legendary paintings, which were discovered at Stratford upon Avon. 
sentation of a figure standing on a pedestal, and fastened to it by a chain, which a demon below is also holding. The figure grasps in one hand a cup with demons issuing from it, and in the other a bag full of money. This may be intended to be an allegorical representation of the same subject. In the painting of the Doom in the same chapel, the figures of the Deadly Sins are portrayed as being hurried off to perdition, Pride being borne aloft on the shoulders of a demon with a donkey's head.

As at Little Horwood, so in the cases cited at Raunds, Brooke, Crostwight, Stokesby and Ingiatestone, the subject of the Seven Deadly Sins is found side by side with that of St. Christopher, nor could two subjects be more appropriately associated, as in both the evils of the crowning sin of Pride are clearly and prominently defined. 